\title{
First record of an epibiosis between the sand crab Emerita analoga (Stimpson, 1857) (Decapoda: Hippidae) and the mussel Semimytilus algosus (Gould, 1850) (Bivalvia, Mytilidae) in southern Peru
}

Received: 11 March 2005/ Revised: 27 July 2005 / Accepted: 27 July 2005 / Published online: 24 September 2005

(C) Springer-Verlag and AWI 2005

\begin{abstract}
Coastal zones of the Humboldt Current Upwelling System (HCUS) are composed both of rocky and sandy beaches inhabited by macrozoobenthic communities. These show oscillating changes in the dominance of species; the abundance of the sand crab Emerita analoga is linked to phases of the El Niño Southern Oscillation (ENSO). The biogenic surfaces of these crabs serve as substrate for opportunistic colonizers. This study is the first record of an epibiosis between E. analoga and the rock mussel Semimytilus algosus, detected at a southern Peruvian sandy beach. Mussels fouled a wide size-range of adult E. analoga $(7.3 \%)$ but they themselves belonged to small-size classes. The largest $S$. algosus was $17.4 \mathrm{~mm}$ in length. Highest permanence of epibionts was found on larger sand crabs (maximum between 24 and $27 \mathrm{~mm}$ ). Significantly more mussels were found on the ventral surface $(39.4 \%)$ compared to 10 other surface areas of the sand crab. Possible benefits and disadvantages of the observed epibiosis for both the basibiont and the epibiont are discussed.
\end{abstract}

Communicated by H.-D. Franke

M. J. Villegas

Departamento de Ciencias del Mar,

Universidad Arturo Prat, Av. Arturo Prat 2120,

Iquique, Chile

E-mail: mario.villegas@unap.cl

W. Stotz

Grupo de Ecología y Manejo de Recursos,

Departamento de Biología Marina,

Universidad Católica del Norte, Casilla 117,

Coquimbo, Chile

E-mail: wstotz@ucn.cl

J. Laudien $(\bowtie)$

Alfred Wegener Institute for Polar and Marine Research,

P.O. 120161, 27515 Bremerhaven, Germany

E-mail: jlaudien@awi-bremerhaven.de

Tel.: + 49-471-48311315

Fax: + 49-471-48311918
Keywords Humboldt Current Upwelling System • Epibiosis $\cdot$ Fouling $\cdot$ Semimytilus algosus $\cdot$ Emerita analoga

\section{Introduction}

The coastal Humboldt Current Upwelling System (HCUS) is one of the most productive marine ecosystems (Mann and Lazier 1991; Escribano et al. 1997; Marín et al. 2001). The system is fuelled by upwelling of nutrients, which stimulate the primary and secondary production (Escribano et al. 1997; Marín et al. 2001). Coastal zones of the HCUS consist of rocky as well as sandy beaches colonized by a diverse macroinfauna of invertebrates contributing to a high biomass (Soto 1985; Jaramillo et al. 1993; Arntz and Fahrbach 1996). There are many studies on the patterns of macrofaunal zonation in exposed sandy beaches of the coastal upwelling system (e.g. Jaramillo et al. 1993, 2001; Jaramillo and McLachlan 1993), showing that changes in beach morphodynamic result in significant community responses of the intertidal macroinfauna. Communities of sandy beaches of south and central Peru show clear fluctuations of dominant species such as the surf clams Mesodesma donacium and Donax marincovichi, and the sand crab Emerita analoga. The main reasons for these are natural climate variability as the El Niño Southern Oscillation (ENSO) (Tarazona et al. 1985; Arntz et al. 1987; Arntz and Fahrbach 1996) and overexploitation.

The sand crab E. analoga (Crustacea, Anomura, Hippidae) is a widespread and abundant decapod inhabiting exposed sandy beaches of the Pacific coast (e.g. Contreras et al. 1999), and is a characteristic specie of the swash zone (Jaramillo et al. 1993, 2001; Contreras et al. 1999). It can appear in high abundance forming aggregations at certain water temperatures, food availability and beach morphodynamics (Perry 1980; Dugan 1994; Jaramillo and McLachlan 1993; Contreras et al. 1999). The combination of substrate generalist characteristics and the unique orientation and swimming 
ability of $E$. analoga may be a key to its high abundance and wide distribution in the intertidal zone of exposed sandy beaches (Dugan et al. 1994, 2000). The hard carapace of this crab offers free substratum for species colonizing hard structures (Wahl 1989; Gili et al. 1993).

For metamorphoses and settlement the free-living larvae of sessile hard bottom invertebrates are highly dependent on the availability of a suitable substratum (Sebens 1985; Gili et al. 1993). The coastal area of northern Chile and southern to central Peru is dominated by soft bottom habitats, while rock substratum is scarce. Biogenic surfaces can also serve as settlement substrates resulting in epibiosis, a close association between two different species: a basibiont (the substrate organism) fouled by an epibiont (organism growing attached to a living surface; Wahl 1989). Host species reported from sandy beaches are mainly molluscs and crustaceans (Conover 1979; Warner 1997; Olabarría 2000), fouled by diverse sessile invertebrates. Such an association usually includes both benefits and disadvantages for epi- and basibiont (Wahl 1989; Gili et al. 1993), which have a more prominent effect under strong physical environmental conditions such as wave exposure and currents (Jackson 1977; Wahl 1989; Olabarría 2000). In southern Peru we observed that E. analoga was fouled by the rock mussel Semimytilus algosus, a common inhabitant of the low rocky intertidal fringe in central Chile, distributed between Ecuador and ChiloeIsland (approximately $42^{\circ} \mathrm{S}$, Caro and Castilla 2004). The aim of this study was to describe this epibiosis and to discuss possible effects for both the host and the epibiont.

\section{Materials and methods}

\section{Study area}

This study was carried out at a large sandy beach $(110 \mathrm{~km})$ at the border between Chile (Arica) and Peru (Boca del Rio locality) $\left(18^{\circ} 12^{\prime} \mathrm{S} ; 70^{\circ} 35^{\prime} \mathrm{W}\right)$ (Fig. 1). The beach is fully exposed to the breaking waves resulting in the typical beach morphology with flat and steeper areas. Three faunal zones (upper, middle and lower shore) characterize these beaches, where $E$. analoga typically inhabits the lower shore (swash zone) along the Chilean coast. However, this sand crab was also found on the lower levels of the middle shore in the sandy beaches of Peru (McLachlan and Jaramillo 1995).

\section{Sampling and analysis}

Sand crab E. analoga fouled by the mussel S. algosus were collected in the intertidal zone along the beach. Individuals of $E$. analoga covering the whole size range were sampled within a time period of $5 \mathrm{~min}$ each in two $100 \mathrm{~m}$ wide areas. The abundance of E. analoga in the

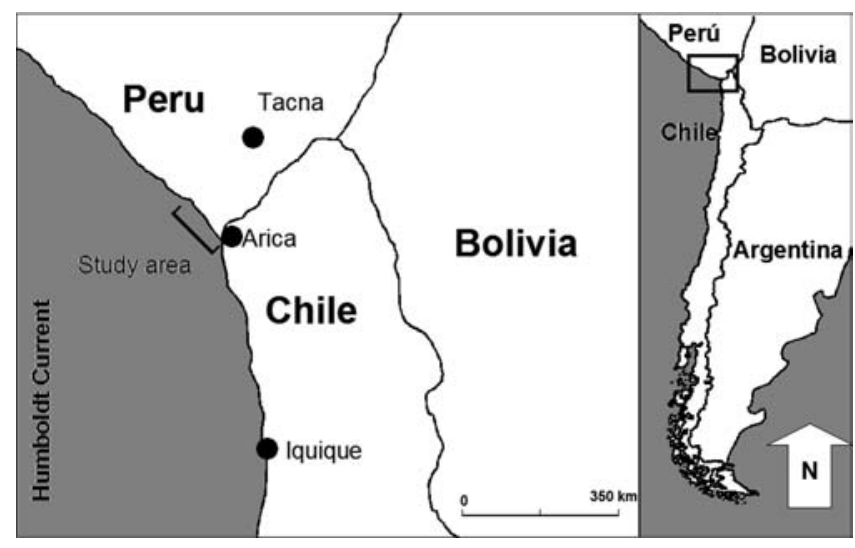

Fig. 1 Map indicating the study area, which is part of the coastal Humboldt Current Upwelling System $\left(18^{\circ} 12^{\prime} \mathrm{S}, 70^{\circ} 35^{\prime} \mathrm{W}\right)$ at the border between Chile and Peru

study area was determined using a cylindrical corer $(10 \mathrm{~cm}$ in diameter). Individuals were fixed in $5 \%$ formalin. Thereafter individuals were measured (length of carapace) to the nearest $0.1 \mathrm{~mm}$ and observed under a binocular microscope in order to detect epibionts. Epibiotic mussels were identified and counted, their position on the basibiont was recorded and their length was measured. S. algosus was found attached to 11 different surface areas of E. analoga (see also Fig. 5): (1) ventral side, (2) right side of carapace, (3) inferior left maxilliped, (4) area between first and second pereiopod, (5) anterior right edge of carapace, (6) dactylus of first pereiopod, (7) superior pereiopod left, (8) left side of carapace, (9) superior pereiopod right, (10) dorsal carapace, (11) area between coxae and carapace. Images of fouled areas were taken using a digital camera (Canon G3 - Power shot) and a binocular microscope (Carl Zeiss) with 230 magnification.

\section{Results}

The abundance of E. analoga in the study area was 65 ind $\mathrm{m}^{-2}$. Among a total of 300 individuals of $E$. analoga analysed, $7.3 \%(n=22)$ were fouled by $S$. algosus. These mussels were found on sand crabs ranging from 18 to $33 \mathrm{~mm}$ in caparace length, but mostly on crabs with 24 to $27 \mathrm{~mm}$ (Fig. 2). The highest number of epibionts per crab was three; however, most common was just one epibiont (Fig. 3). There was no clear relationship between the fouling intensity and the size of the basibiont $\left(R^{2}=0.0065\right)$. Fouling $S$. algosus ranged from 0.1 to $17.4 \mathrm{~mm}$ in anterior-posterior length (Fig. 4); smaller bivalves (below $5 \mathrm{~mm}$ shell length) were most abundant. Most mussels were found attached to zone 1 $(39.4 \%)$ and zone $2(18.2 \%)$; other zones of minor importance were zone $3(9.1 \%)$ and zones $4-6$, with $6.1 \%$ each (Fig. 5). Figure 6 illustrates the fouling of different surface areas of $E$. analoga by the mussel S. algosus. 
Fig. 2 Size frequency distribution of the sand crab E. analoga without (square box) and with (filled square box) epibiontic mussels $S$. algosus, found at the large sandy beach between Arica and the Boca del Rio locality

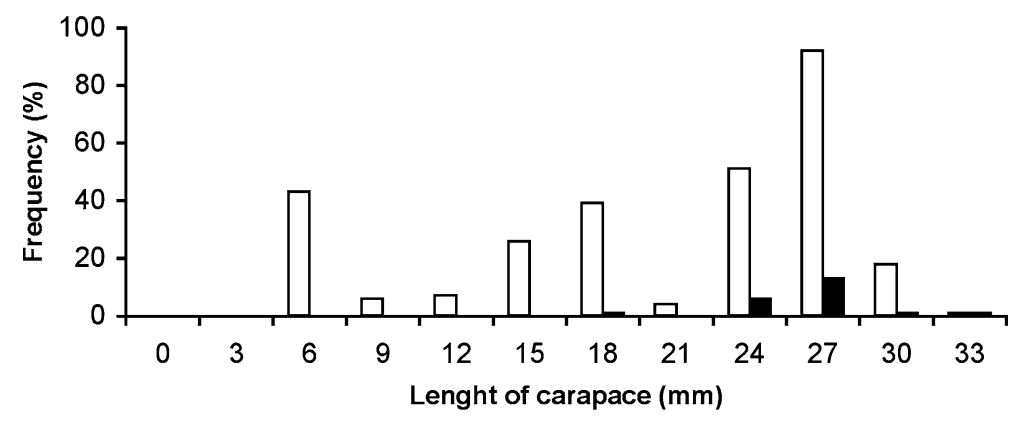

Fig. 3 Number of mussels S. algosus found on $E$. analoga as a function of the host's carapace length

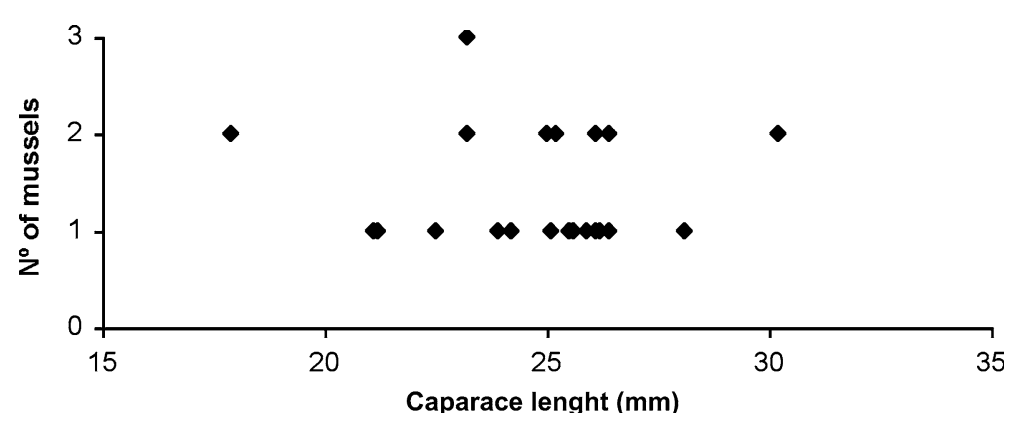

Fig. 4 Size frequency distribution of mussels $S$. algosus fouling the sand crab E. analoga

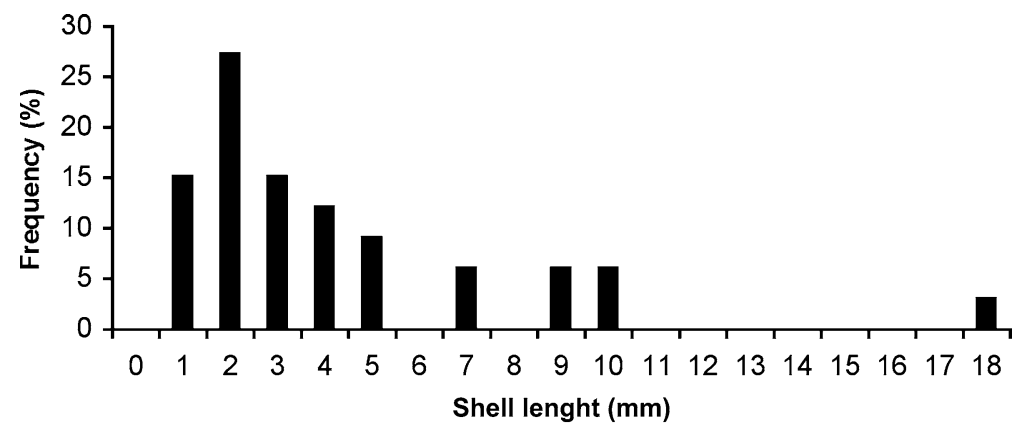

\section{Discussion}

Biogenic substrates are commonly used as settling substrates by hard-bottom colonizers, especially in dynamic soft bottoms where no or only a few other substrates are available. This especially holds true for our study site, a long highly exposed beach without solid rock. Hard bottom is very scarce over a long distance of coastline, apparently resulting in a high competition pressure for settling surfaces. Crustacean carapaces and shells of molluscs of different species were reported as potential substrates for colonizers in such soft-bottom habitats
Fig. 5 Frequency distribution of mussels $S$. algosus attached to different surface areas (1-11) of its host $E$. analoga; inserted photographs (from left to right): left, ventral and right side of the host (see also Materials and methods)

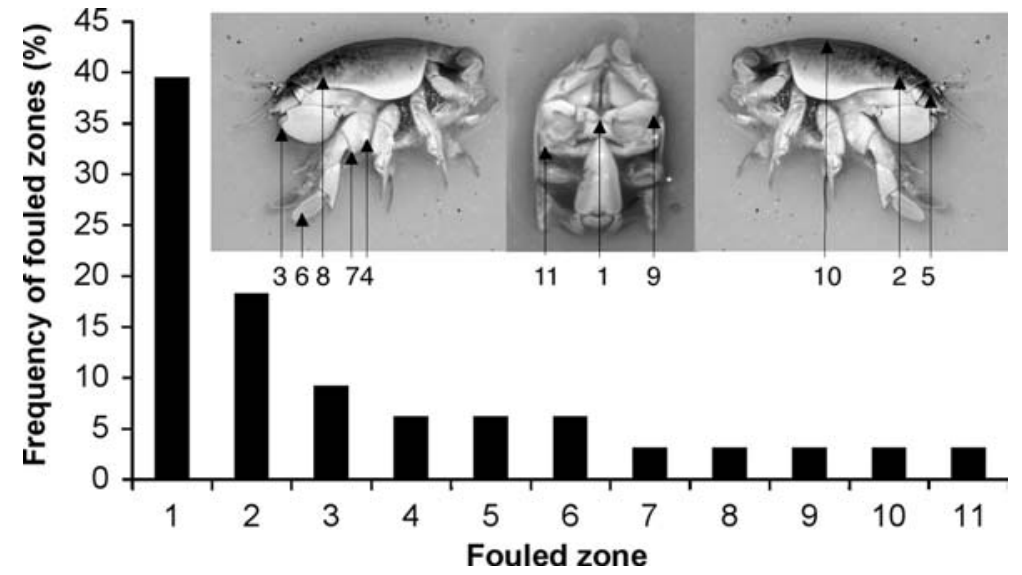


Fig. 6 Photographs of mussels $S$. algosus fouling the crab E. analoga; a on the ventral surface between the pereiopods, b on the right side of the carapace, $\mathbf{c}$ on the anterior right part of the carapace, $\mathbf{d}$ on the left inferior maxilliped, e distal on the first pereiopod and $\mathbf{f}$ large mussel $(17.4 \mathrm{~mm})$ on the dorsal surface
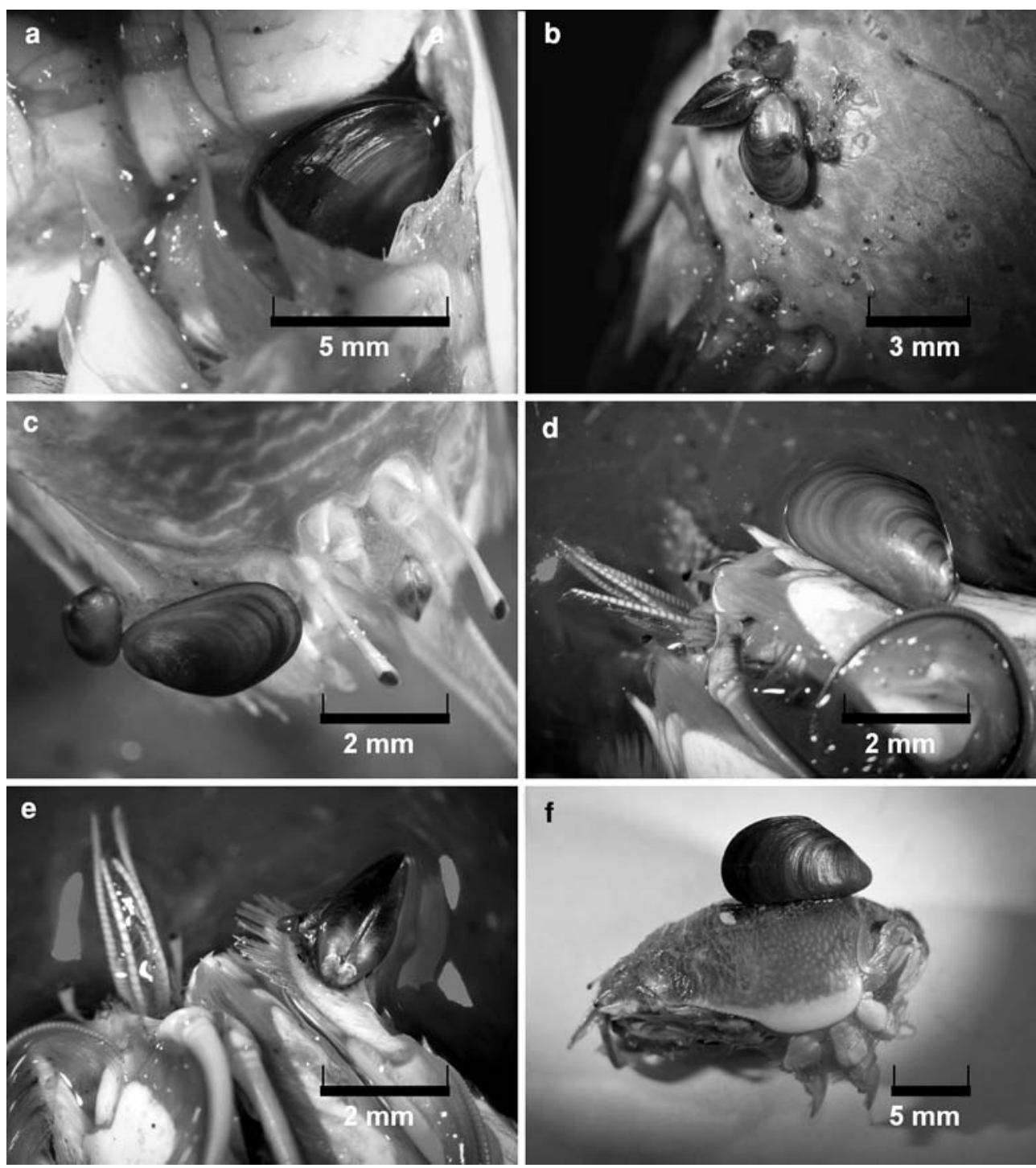

(Conover 1979; Gili et al. 1993; Olabarría 2000). However, an association between the sand crab E. analoga and the rock mussels $S$. algosus has not yet been reported. The latter dominates exposed rocky intertidal communities in the low and middle latitudes of Pacific South America (Tokeshi and Romero 1995) and is recognized as an important primary colonizer in the HCUS (Tarazona et al. 1985; Tokeshi and Romero 1995). The larval phase of this mussel species varies from 17 to 20 days. Recruitment of $S$. algosus occurs throughout the year with major peaks in summer and, secondarily, winter months (June-August), showing interannual changes during EN (Navarrete et al. 2002).

Successful larval settlement and metamorphosis of Mytilidae depend on the availability of suitable substrata. Substrate choice is controlled by physical and biotic factors, with specific chemical stimuli for metamorphosis (e.g. living tissue of corals, Mokady et al. 1992; filamentous algae or filamentous structures, Davis and Moreno 1995). Under favourable substrate conditions, the larva crawls around for a certain period of time, and then gradually stops moving in response to a hierarchy of stimuli; it protrudes its foot out of the shell and quickly secretes a single byssus thread, thereby attaching to the substrate (Lutz and Kennish 1992). Unlike the related mussel Mytilus edulis, which can form vast beds in soft-bottom habitats, for example, of the Baltic Sea (e.g. Schwenke 1969; Reusch 1994; Laudien and Wahl 1999), S. algosus is exclusively dependent on hard substrates. Besides bedrock, secondary hard bottoms such as the valves of the surf clam $M$. donacium can serve as substrate. Before EN 1982 S. algosus settled on a $M$. donacium bed in central Peru attaining densities of 281 ind $\mathrm{m}^{-2}$ (Fig. 7). Although under unfavourable conditions the mussel can close its shells and survive several days (Schiedek and Currie 2002) S. algosus suffered a mass mortality when the clams were covered by sediment during a long period of strong swell (Arntz et al. 1987). Since EN 1998 M. donacium has not recovered former densities along the whole Peruvian coastline (Stotz et al. 2003). 


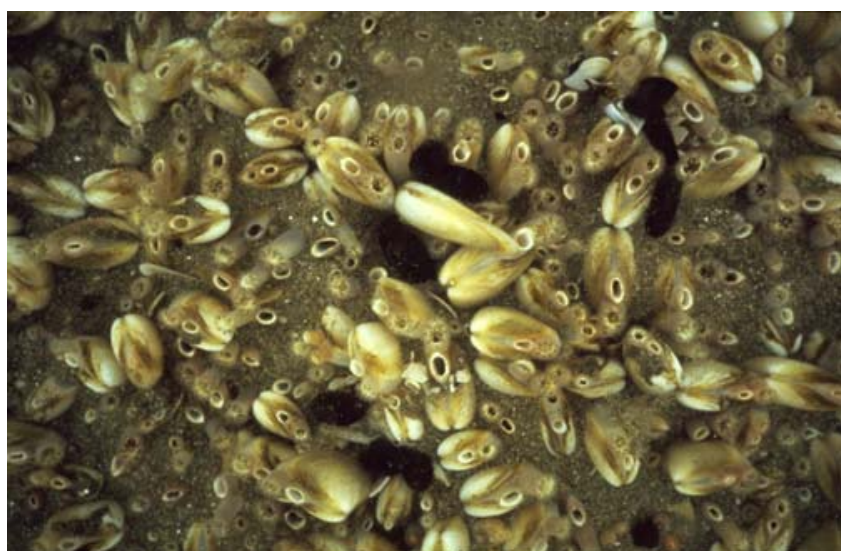

Fig. 7 Underwater photograph showing $S$. algosus settling on the surf clam M. donacium in central Peru before ENSO 1982

The sand crab E. analoga substituted the surf clams (Tarazona et al. 1985; Arntz et al. 1987) and became available as settlement substrate for the pioneer mussels. As a consequence mussels were observed fouling a wide size range of adult $E$. analoga. Most epibiotic mussels belonged to a correspondingly small-size class of probably young individuals. The highest permanence of epibionts was found on larger basibionts suggesting that bigger hosts offer more shelter and stability for the mussel to protect it from physical factors such as wave exposure. The evolutionary response of sessile basibionts to a potential epibiosis includes three classes of adaptations: tolerance, avoidance and defence (Wahl 1989). In crustaceans the mechanic defence such as the periodic renewal of the carapace due to moulting and the 'sanding' in dynamic high energy sandy beaches might regulate the colonization rate (Wahl 1989; Gili et al. 1993). Thus large-sized sand crabs might be more susceptible to fouling as the molt interval is longer and the crabs inhabit zones with more stable conditions.

Defence may be costly while tolerance entails both benefits and disadvantages for epi- and basibiont. According to Wahl and Mark (1999), specific and obligate epibionts are rare. Consequently, the majority of described associations are classified as facultative. The association between E. analoga and S. algosus probably involves a complex network of cost-benefit factors for the two species. In soft bottoms the opportunistic settlement of $S$. algosus on E. analoga may be the only opportunity for successful larval metamorphosis. The percentage of fouled E. analoga $(7.3 \%)$ appears important considering the density of sand crabs (about 65 ind $\mathrm{m}^{-2}$ ) in the study area. The abundance of E. analoga varies between 10 and 85 ind $\mathrm{m}^{-2}$ (Arntz et al. 1987) and can reach maximum values of 111.6 ind $\mathrm{m}^{-2}$ before EN (Tarazona et al. 1985). In southern Chile even much higher values of 1675 ind $\mathrm{m}^{-2}$, related to temporal variability in recruitment, were reported (Contreras et al. 1999).
Mainly juvenile mussels were attached to the crabs. Individuals of $S$. algosus in northern and central Chile (lat $30^{\circ}$ ) reach a maximum size exceeding $70 \mathrm{~mm}$ (Gonzáles et al. 1980; Tokeshi and Romero 1995), are hermaphroditic with mature gametes during the entire year (Gonzáles et al. 1980), and may obtain sexual maturity at $20 \mathrm{~mm}$ (Gallardo 2001). In the present study the maximum size of epibiotic $S$. algosus was a little smaller $(17.4 \mathrm{~mm})$. However, our study site was $1300 \mathrm{~km}$ north of the former study area and it is possible that in low latitudes the bivalves reach sexual maturity in smaller size classes (according to Thorson 1950). $S$. algosus on $E$. analoga are unlikely to commonly reach size necessary for reproduction. However, small mussels may colonize other substrates later on by detaching from the substrate and drifting elsewhere while larger individuals may undergo a lateral movement (Tokeshi and Romero 1995). Under favourable conditions and when more biogenous substrates for settlement are available (e.g. surf clams $M$. donacium), S. algosus may reach higher densities (Arntz 1987; Arntz and Fahrbach 1996), and epibiosis may facilitate the dispersal and contribute to gene flow of the rock mussel populations even more prominently.

Epibiosis is apparently unfavourable for the basibiont. Fouling by calcareous epibionts causes an increase in mass, and therefore may reduce buoyancy (Wahl 1989). In the specific case of E. analoga, fouling is maximal on the anterior side (Fig. 5; zone 1, approximately $40 \%$ ). The crabs are normally burrowed in the sand and only the anterior part of the carapace and the first appendices are exposed (Fig. 8; Ruppert et al. 2004; Dugan 2000). In this position, the sand crab filters and mussel larvae transported with the water current may be attracted by the hard surface and attach. On the other hand, mussel larvae might settle when crabs leave the sediment to undergo tidal migrations (Dugan et al. 2000). It is unknown why the right sides of the crabs were fouled more frequently than the left one. Maybe this can be explained by an asymmetrical use of the mouth tools or by the dominant current direction. However, to test these hypothesis further observations on the filtering behaviour and shallow subtidal current measurements are necessary.

Due to increased drag and mass the epibiont is likely to reduce the growth of the crabs (Wahl 1997) and might impact their migration behaviour. Furthermore, mechanical attachment of larger epibionts occasionally damages surfaces of the basibiont (Witman and Suchanek 1984; Wahl 1989).

In top-down controlled systems, epibiosis can strongly influence community dynamics, affecting many epibiont-basibiont-consumer interactions (Wahl 1989; Wahl et al. 1997; Laudien and Wahl 1999, 2004). In the western Baltic, for instance, the sea star Asterias rubens preys preferably on unfouled mussels (M. edulis) and the predation pressure decreases significantly when the mussels are fouled by hydrozoan and algae. This beneficial effect of fouling is known as associational resis- 
Fig. 8 Schematic drawing of a burrowed sand crab E. analoga fouled by the mussel $S$. algosus

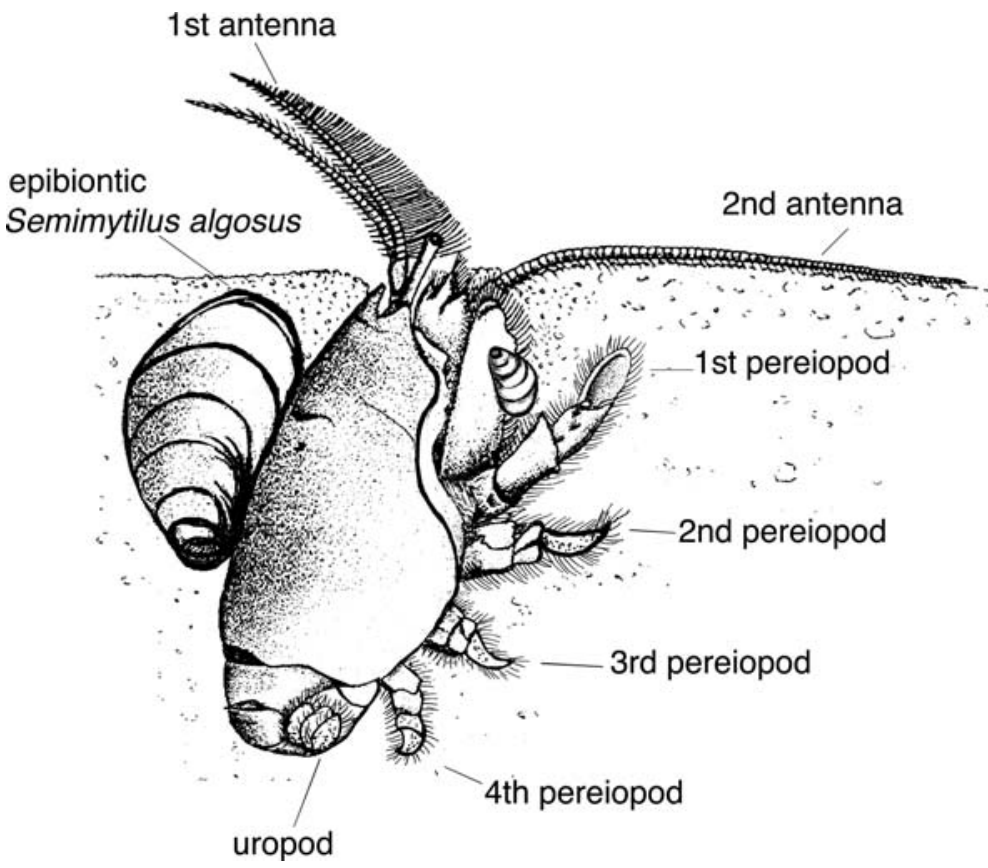

tance (Laudien and Wahl 1999, 2004). However, in the case of the rock mussel-sand crab association, the opposite effect ('shared doom effect', Laudien and Wahl 1999) might occur when epibiotic individuals of larger size reduce the ability of $E$. analoga to escape from predators by increasing mass, reducing motility, and ultimately prolonging the burrowing time during the tidal migration (Dugan et al. 2000). A future study of the burrowing behaviour under predation pressure might give a deeper insight into the cost and benefits of this epibiosis between $S$. algosus and E. analoga.

Acknowledgements Sampling was conducted during the fieldwork of the FIP project 2001-24 carried out by the Group of Ecology and Management of Resource (ECOLMAR). We especially thank Pablo Araya for his assistance in the field. Thanks are also due to Ivan Hinojosa and Sebastian Boltaña who helped taking the digital photos. Wolf Arntz provided underwater pictures of $S$. algosus $-M$. donacium associations. We are grateful to Renate Kuchta who helped with Fig. 8 and to Domingo Lancellotti and Heinz-Dieter Franke who gave valuable comments on an earlier version of the manuscript. This study was conducted in the frame of the EU project CENSOR (Climate variability and El Niño southern oscillation impacts for natural resources and management).

\section{References}

Arntz WE, Brey T, Tarazona J, Robles A (1987) Changes in the structure of shallow sandy-beach community in Perú during an EL Niño event. In: Payne AIL, Gulland JA, Bink KH (eds) The Benguela and comparable ecosystems. S African J Mar Sci 5:645-658

Arntz WE, Fahrbach E (1996) NIÑO: Experimento climatico de la naturaleza. Causas físicas y efectos biologícos. Fondo de la Cultura Economica Editores, Mexico

Caro AU, Castilla JC (2004) Predator-inducible defences and local intrapopulation variability of the intertidal mussel Semimytilus algosus in Central Chile. Mar Ecol Prog Ser 276:115-123
Contreras H, Defeo O, Jaramillo E (1999) Life History of Emerita analoga (Stimpson) (Anomura, Hippidae) in a sandy beach of south central Chile. Estuar Coast Shelf Sci 48:101-112

Conover MR (1979) Effect of gastropod shell characteristics and hermit crabs on shell epifauna. J Exp Mar Biol Ecol 40:81-94

Davis AR, Moreno CA (1995) Selection of substrata by juvenile Choromytilus chorus (Mytilidae): are chemical cues important? J Exp Mar Biol Ecol 191:167-180

Dugan JE, Hubbard DM, Wenner AM (1994) Geographic variation in life history of the sand crab, Emerita analoga (Stimpson) on the California coast: Relationships to environmental variables. J Exp Mar Biol Ecol 181:255-278

Dugan JE, Hubbard DM, Lastra M (2000) Burrowing abilities and swash behaviour of three crabs, Emerita analoga Stimpson, Blepharipoda occidentalis Randall, and Lepidopa californica Efford (Anomura, Hippoidea), of exposed sandy beaches. J Exp Mar Biol Ecol 255:229-245

Escribano R, Irribarren C, Rodriguez L (1997) Influence of food quantity and temperature on development and growth of the marine copepod Calanus chilensis from northern Chile. Mar Biol 128:281-288

Gallardo C (2001) Control de celulas neurosecretoras sobre el proceso gametogénico en Semimytilus algosus Gould, 1850 (Bivalvia: Mitilidae) Tesis para optar al titulo de Biologo Marino. Facultad de Ciencias del Mar, Universidad Católica del Norte, Chile

Gili JM, Abelló P, Villanueva R (1993) Epibionts and intermoult duration in crab Bathynectes piperitus. Mar Ecol Prog Ser 98:107-113

González J, Villagra J, Hinojosa M, Becerra R (1980) Potencialidad del cultivo en balsa de Semimytilus algosus (Gould) 1850, en la Bahía de Concepcion (Mollusca, Bivalvia, Mytilidae) Boletim do Instituto Oceanografico, Sao Paulo. Sao Paulo 29:187-189

Jackson JBC (1977) Competition on marine hard substrata: The adaptative significance of solitary and colonial strategies. Am Nat 111:743-767

Jaramillo E, McLachlan A, Coetzee P (1993) Intertidal zonation patterns of macroinfauna over a range of exposed sandy beaches in South-central Chile. Mar Ecol Prog Ser 101:105-118

Jaramillo E, McLachlan A (1993) Community and populations responses of the macroinfauna to physical factors over a range of exposed sandy beaches in South-central Chile. Estuar Coast Shelf Sci 37:615-624 
Jaramillo E, Contreras H, Duarte C, Quijón P (2001) Relationships between community structure of the intertidal macroinfauna and sandy beach characteristics along the Chilean coast. Mar Ecol 22:323-342

Laudien J, Wahl M (1999) Indirect effect of epibiosis on host mortality: Seastar predation on differently fouled mussels. Mar Ecol 20:35-47

Laudien J, Wahl M (2004) Associational resistance of fouled blue mussels (Mytilus edulis) against starfish (Asterias rubens) predation: relative importance of structural and chemical properties of the epibionts. Helgol Mar Res 58:162-167

Lutz RA, Kennish M (1992) Ecology and morphology of larval and early postlarval mussels. In: Gosling EM (ed) The mussel Mytilus: ecology, physiology, genetics, and culture. Dev aquacult fish science, vol 25. Elsevier, Amsterdam, pp 53-85

Mann KH, Lazier JRN (1991) Dynamics of marine ecosystems Biological-physical interactions in the ocean. Blackwell Scientific Publications, Oxford

Marín VH, Escribano R, Delgado LE, Olivares G, Hidalgo P (2001) Nearshore circulation in coastal upwelling site off the Northern Humboldt current system. Cont Shelf Res 21:13171329

McLachlan A, Jaramillo E (1995) Zonation on sandy beaches. Ocean Mar Biol Ann Rev 33:305-335

Mokady O, Arazi G, Bonar DB, Loya Y (1992) Settlement and metamorphosis specificity of Lithophaga simples Iredale (Bivalvia: Mytilidae) on Red Sea corals. J Exp Mar Biol Ecol 162:243-251

Navarrete SA, Broitman B, Wieters EA, Finke GR, Venegas RM, Sotomayor A (2002) Recruitment of intertidal invertebrates in the southeast Pacific: Interannual variability and the 1997-1998 El Niño. Limnol Oceanogr 47:791-802

Olabarría C (2000) Epibiont mollusc on neogastropod shells from sandy bottoms, Pacific coast of Mexico. J Mar Biol Ass UK 80:291-298

Perry DM (1980) Factors influencing aggregations patters in sand crab Emerita analoga (Crustacea: Hippidae). Oecologia 45:379384

Ruppert EE, Fox RS, Barnes RP (2004) Invertebrate Zoology-A functional evolutionary approach, 7th edn. Brooks Cole/ Thomson, Belmont, CA, pp 963
Reusch T (1994) Factors structuring the Mytilus- and Zosteracommunity in the western Baltic: an experimental approach. PhD Thesis, University of Kiel, Kiel

Sebens K (1985) The ecology of the rocky subtidal zone. Am Sci 73:548-557

Schiedek D, Currie B (2004) Metabolic responses of two macrobenthic species to naturally occurring hydrogen sulphide. Southern African Marine Science Symposium (SAMSS 2002): Currents Coasts Communities

Schwenke H (1969) Untersuchungen zur marinen Vegetationskunde. Kieler Meeresforsch 25:163-170

Soto R (1985) Effects of the 1982-83 El Niño phenomenon on ecosystems of the 1 Region. Invest Pesq (Santiago) 32:199-206

Stotz W, Lancellotti D, Lohrmann K, Von Brand E (2003) Repoblamiento de bancos de Macha Mesodesma donacium en playa las machas de Arica, I Región, Chile. Proyecto FIP 200124 , informe final

Tarazona J, Arntz WE, Canahuire E. Ayala Z, Robles A (1985) Modificaciones Producidas durante "El Niño" en la Infauna Bentónica de Areas Someras del Ecosistema de Afloramiento Peruano. In: Arntz W, Landa A, Tarazona J. (eds) "El Niño" su Impacto en la Fauna Marina. Instituto del Mar del Perú

Thorson G (1950) Reproductive and larval ecology of marine bottom invertebrates. Biol Rev 25:1-45

Tokeshi M, Romero L (1995) Filling a gap: dynamics of space occupancy on a mussel-dominated subtropical rocky shore. Mar Ecol Prog Ser 119:167-176

Wahl M (1989) Marine epibiosis I Fouling and antifouling: some basic aspects. Mar Ecol Prog Ser 58:175-189

Wahl M (1997) Increased drag reduces growth of snails: comparison of flume and in situ experiments. Mar Ecol Prog Ser 151:291-293

Wahl M, Mark O (1999) The predominantly facultative nature of epibiosis: experimental and observational evidence. Mar Ecol Prog Ser 187:59-66

Warner GF (1997) Occurrence of epifauna on the periwinkle, Littorina littorea (L.), and interactions with the polychaete Polydora ciliata (Johnston). Hydrobiologia 355:41-47

Witman JD, Suchanek TH (1984) Mussels in flow: drag and dislodgement by epizoans. Mar Ecol Prog Ser 16:259-268 